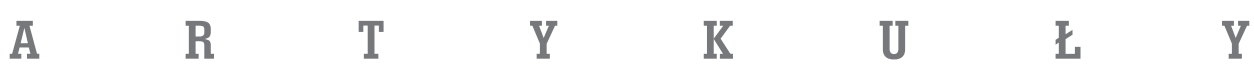

Franciszek Tyszka

European University Institute in Florence

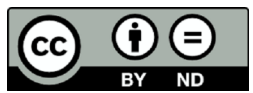

\title{
Węgierskie impasy historyczne na tle europejskiego rozwoju społecznego w ujęciu Istvána Bibó
}

Zarys treści: Celem artykułu jest omówienie, na przykładzie Węgier i w oparciu o pisma Istvána Bibó, rozbieżności w rozwoju społecznym Europy Zachodniej i Środkowo-Wschodniej na przestrzeni wieków. Były one skutkiem wstrząsów politycznych, jakie spadły na kraje środkowoeuropejskie między XVI i XX wiekiem.

Summary: This article explores, on the case of Hungary and based on István Bibós works, the reasons and consequences of the split between the Western and Central-European social development. These differences emerged and intensified with successive political upheavals in the Central-European countries betewwn $16^{\text {th }}$ and $20^{\text {th }}$ century.

Słowa kluczowe: rozwój społeczny, Węgry, Europa Środkowa, antydemokratyczny nacjonalizm, histeria wspólnotowa, marksizm.

Keywords: Social development, Hungary, Central Europe, Antidemocratic nationalism, „collective hysteria", Marxism.

István Bibó (1911-1979) to jeden z najważniejszych węgierskich myślicieli społecznych i politycznych XX wieku. Niełatwo zaklasyfikować jego dorobek naukowy. Rozpoczął go i zakończył tekstami z problematyki prawa międzynarodowego. Jego prawdziwą pasją była historia, ale pisząc o niej, nigdy nie stronił od subiektywnych ocen. Nie był historykiem, nie interesowała go historia sama w sobie i nie badał jej bezinteresownie. Zajmował się historią europejskiego rozwoju społecznego, ale tylko po to, by lepiej zrozumieć mechanizmy polityki czy może lepiej - środkowoeuropejskie „korzenie totalitaryzmów”, jakby powiedziała Hannah Arendt, z którą zresztą bywa często porównywany ${ }^{1}$.

1 I. Z. Dénes, Three Concepts of Liberty: István Bibó's, Hannah Arendt's and Isaiah Berlin's Interpretations. 
Zainteresowanie polityką na polu teoretycznym łączył z zaangażowaniem w polityczne życie Węgier, co dodawało jego twórczości naukowej dodatkowych bodźców. Był moralnym i intelektualnym punktem odniesienia dla węgierskiej opozycji antykomunistycznej lat 80 . XX wieku. Do demokratycznego przesłania dzieła Bibó odwoływały się też mniej lub bardziej wszystkie najważniejsze węgierskie partie polityczne powstałe w czasie transformacji ustrojowej po 1989 roku.

$\mathrm{Na}$ Uniwersytecie w Segedynie ukończył prawo i politologię. Na stypendium w Wiedniu i w Genewie uczęszczał na wykłady wielu znanych filozofów prawa, jak Alfred Verdross czy Hans Kelsen. Jednak największe wrażenie zrobił na nim Guglielmo Ferrero, włoski badacz dziejów dyplomacji. W roku 1945 - na początku trzyletniego okresu węgierskiej demokracji - objął stanowisko w Ministerstwie Spraw Wewnętrznych i wstąpił do Narodowej Partii Chłopskiej. Wierność słowu pisanemu i wyznawanym wartościom przypłacił kilkuletnim więzieniem. Po raz pierwszy w 1944 roku, gdy w czasie szalejącego na Węgrzech terroru „strzałokrzyżowców” (nyilaskeresztesek) wydawał Żydom zaświadczenia o mieszanych małżeństwach. Po raz drugi - w 1956 roku - gdy zaangażowanie w rewolucję budapeszteńską okupił prawie sześcioletnim pobytem $\mathrm{w}$ celi więziennej. Będąc ministrem stanu w rewolucyjnym rządzie Imre Nagya, gdy wojska radzieckie wkroczyły do Budapesztu, jako jedyny przedstawiciel nowych władz pozostał w budynku parlamentu, gdzie opracował program rewolucji. Przez niemal cały okres komunizmu jego dzieła były „na indeksie" i dopiero w 1986 roku opublikowano trzy tomy jego pism².

Najważniejsze dzieła napisał w latach 40. ubiegłego wieku i spośród przywołanych w niniejszej pracy większość pochodzi z tego okresu. Próbował w nich dotrzeć do źródeł serii impasów i „ślepych uliczek” we wschodnioeuropejskim rozwoju społecznym i politycznym. Oba terminy oddają tę samą treść, co termin „bezruch” i właśnie modelowi zachodniemu Bibó przypisuje „ruch”, w opozycji do „bezruchu" środkowowschodnich modeli. W niniejszym artykule chciałbym na podstawie wybranych pism Istvána Bibó spróbować odpowiedzieć na pytanie, jakie były dzieje i przyczyny tej opozycji.

\section{Początki europejskiej organizacji społecznej}

W eseju Sens europejskiego rozwoju społecznego Bibó podjął próbę zdefiniowania istoty polityki i religii jako tych sfer aktywności człowieka, które w największym stopniu kształtują losy ludzkości. Polityka jest działalnością innego rodzaju niż nauka, a „eksperymenty polityczne" są innej natury niż eksperymenty naukowe. Metoda polityki sprowadza się do formułowania - na podstawie zebranych dotąd doświadczeń - pewnych koncepcji, których weryfikacja trwa dziesiątki lat (a w przypadku religii możemy mówić o całych

$2 \mathrm{~W}$ języku polskim dostępna jest książka z czterema esejami Bibó w tłumaczeniu prof. Jerzego Snopka: Istvan Bibó, Eseje polityczne (2012, Universitas). W latach 80., w miesięczniku „Znak”, ukazał się esej Podział władz państwowych dawniej i dziś w tłumaczeniu Adam Parvi (1982/10[335], s. 1226-1245). Poniżej będę się odwoływał również do innych pism Bibó - tłumaczonych przeze mnie bądź prof. Snopka, któremu chciałbym bardzo podziękować za udostępnienie mi ich w nieopublikowanej formie. 
stuleciach). Z racji tego, że jest nieprzewidywalna, działalność polityczna zawsze wiąże się z ryzykiem. Podjęcie go jest jednak jedynym sposobem, by zaprowadzić dane społeczeństwo na wyższy poziom organizacji. Według Bibó za wydarzeniami politycznymi kryją się przede wszystkim struktury społeczne. To one określają możliwości i granice tego, co dzieje się współcześnie i co będzie działo się w przyszłości. Są więc najważniejsze w procesie długiego trwania, by posłużyć się terminem Szkoły Annales. Jednym z jej ważniejszych postulatów jest „powrót do źródeł”, a pojęcie długiego trwania ma zasadnicze znaczenie dla zrozumienia ciągłości zjawisk, postaw, nawet cywilizacji.

O rozwoju społecznym można mówić tylko tam, gdzie podejmowane są realne próby skierowania społeczeństwa na drogę sensownego rozwoju. Nie jest on naturalnym, uniwersalnym czy koniecznym schematem każdej cywilizacji i tylko niektóre z nich podjęły się jego realizacji. Z pełną świadomością długiej, mozolnej i pełnej „impasów” drogi, jaką kroczyło społeczeństwo Europy Zachodniej, Bibó twierdzi, że właśnie ono ostatecznie osiągnęło najwyższy poziom rozwoju. Jego sens widzi w syntezie tradycji grecko-rzymskiej oraz chrześcijaństwa. Ta pierwsza objawiała się $\mathrm{w}$ dążeniu do stworzenia racjonalnych form społecznych poprzez zaprowadzenie takiej formy panowania, która wykraczałaby poza władzę osobistą i była potwierdzona w systemie praw. Chrześcijaństwo zaś dążyło do uchronienia życia człowieka od strachu, nienawiści i przemocy, a za cel postawiło sobie organizację społeczeństwa w poczuciu poszanowania godności bliźniego.

Jak wyglądały początki zachodniej organizacji społecznej? Bibó za jej fundament przyjmuje „współpracę” dwóch instytucji: królestwa plemiennego i Kościoła Katolickiego. Kler, jako jedyna warstwa wykształcona, mógł przyswoić dziedzictwo rzymskie i kształtować organizację społeczną, obwarowując władzę królewską prawami i obowiązkami. Miało to olbrzymie znaczenie dla późniejszego rozwoju praw i swobód różnych warstw społecznych (łącznie z chłopami), bo umożliwiało im nadzorowanie władzy i przypominanie jej o roli, jaką ma pełnić w państwie. Spisane w XII wieku prawo zwyczajowe dokonało syntezy prawa rzymskiego z obyczajami powstałymi wskutek ingerencji duchowieństwa w życie publiczne. Związki między dworem a społeczeństwem znalazły instytucjonalne odbicie w zgromadzeniach stanowych w XIV wieku. Odtąd władca odpowiadał jeszcze nie w sensie prawnym, ale - będąc pod wpływem duchowieństwa coraz bardziej świadomy swych moralnych obowiązków - we własnym sumieniu przed ludem.

W badaniu źródeł europejskiego rozwoju społecznego Istvána Bibó wyprzedził węgierski historyk István Hajnal - zwolennik materialistycznej teorii w odniesieniu do historii społecznej. Obaj właśnie w średniowieczu, a nie w nowożytnych ideach racjonalnych, doszukiwali się źródła nowoczesnego rozwoju społecznego. Hajnal twierdził, że to nie jakieś nieuchwytne idee, ale społeczeństwo średniowieczne i wywodzący się z niego tradycjonalizm - stworzyło podstawy nowoczesnego rozwoju ${ }^{3}$. Dzięki niemu racjonalizm mógł w ogóle powstać, a wraz z nim ten specyficzny

3 G. Kovács, Hajnal István ès Bibó István történelemszemlélete (Pogląd na historię Istvána Hajnala i Istvána Bibó), [w:] I. Z. Dénes, A szabadsàg kis körei, Budapest 1999. 
wyznacznik europejskości - „fachowość” (szakszerüség), na bazie której narodził się kapitalizm. „Fachowość” była efektem naturalnej ciągłości tradycji średniowiecznej, która pozostawiła po sobie „małe kręgi wolności” (szabadság kis körei) - zdaniem Bibó fundamentalny element rozwoju zachodniego. A jaką spuściznę pozostawił po sobie nowożytny racjonalizm? Jeśli jest to dążenie do jak największej użyteczności i wyzysku - twierdzi Hajnal - to można widzieć w nim raczej hamulcowego sprawy postępu, niż jej orędownika.

Średniowieczne „małe kręgi wolności” z czasem powiększały się i rozprzestrzeniały. Czym one są, precyzuje Bibó:

W klasycznej organizacji feudalizmu życie każdego członka społeczności określały bezpośrednie i osobiste więzi, nie zaś scentralizowane ośrodki władzy i ujednolicone instytucje (...) Naturalnie system ten nie znał jeszcze instytucji, która połączy sprawy wolności i równości, opierał się jednak na bogactwie zagwarantowanych i wzajemnie świadczonych usług, zobowiązań, swobód i praw, kształtujących się w małych kręgach (...) Tak tworzyły się różnego rodzaju więzi oparte na relacji podległości, solidarności, ochronie interesów, które konsekwentnie stawiały opór brutalnym, nastawionym na użyteczność metodom stosowanym przez społeczne i polityczne siły w celu koncentracji władzy i zniewolenia ludzi ${ }^{4}$.

Organizacja społeczeństwa oparta na „małych kręgach wolności” umożliwiła wytworzenie się fachowych zawodów rolniczych i rzemieślniczych, którym nie groziła ingerencja władzy. Ci ludzie dążyli do tego, by kierować się w pracy tylko takimi względami i metodami, które służą danemu zawodowi - dążyli do „fachowości" jako do celu samego w sobie. Właśnie te powoli i drobiazgowo dopracowywane zwyczaje o charakterze lokalnym, ponownie podejmowane i przekształcane przez kolejne pokolenia, doczekały się w rezultacie swego wielowiekowego rozwoju zwieńczenia w postaci praw i swobód obywatelskich.

\section{W poszukiwaniu pierwszej przyczyny wschodniego zastoju}

Organizację społeczeństwa zachodniego przedstawiał Bibó jako pewien model, niedościgniony wzór i punkt odniesienia dla krajów położonych w środkowej części Europy - Węgier, Polski i Czech - którym nie było dane rozwijać się jednocześnie z Zachodem. Nie zawsze z własnej winy. Bibó wielokrotnie podkreślał, że nie można oceniać danego narodu, regionu czy kultury przez pryzmat ich wrodzonego charakteru. Przypisywanie go jest zawsze czynnością wtórną, służącą zwykle temu, by interpretować po swojej myśli aktualną sytuację historyczną. Trudno więc zgodzić się z często spotykanym, ale powierzchownym przekonaniem o jakimś pierwotnym,

4 I. Bibó, A magyar társadalomfejlődés és az 1945. évi változás értelme (Węgierski rozwój społeczny i sens przełomu 1945 roku, tłum. - F.T.), [w:] idem, Válogatott tanulmányok (1945-1949), Budapest 1986, s. 493. 
zasadniczym zacofaniu krajów Europy Środkowo-Wschodniej. Wskazuje się nieraz na prymitywną, archaiczną strukturę społeczną tego regionu: zachodni system feudalny rozpościerał się do granicy Łaby, a za nią panowała strefa niewolniczego, sztywnego poddaństwa. Z kolei swoiste wyznaczniki europejskiego rozwoju społecznego w postaci idei chrześcijańskich, humanistycznych, oświeceniowych i socjalistycznych docierały na Wschód z dużym opóźnieniem i nie w pełnej, oryginalnej formie. Bibó jednocześnie zauważa, że wszystkie te przesłanki istniały, choć w mniejszej mierze, również w Europie Środkowo-Wchodniej. Prawdą jest, że od Europy Zachodniej region ten był przez wieki oddzielony, ale pod względem politycznym, społecznym, gospodarczym to Zachód był mu zawsze najbliższy.

Skoro więc kraje wschodnioeuropejskie były mniej lub bardziej „strukturalnie” przygotowane do zaadaptowania osiągnięć krajów zachodnich, dlaczego tego nie uczyniły? Oddajmy głos węgierskiemu myślicielowi:

Jedną z największych nadziei XIX-wiecznej Europy był ogromny oddźwięk, z jakim europejskie idee wolnościowe spotkały się w Europie Wschodniej. Nadzieja ta - jeśli pominąć Rosję - nie spełniła się, ale faktu, dlaczego region ten odstawał wyraźnie od Zachodu, nie da się wytłumaczyć przyczynami wyłącznie społecznymi (...) Pięćdziesiąt lat wcześniej nie spotkalibyśmy nikogo, kto wychodząc od przyczyn charakterologicznych byłby w stanie przewidzieć, że w połowie XX wieku nie tylko Rosja, ale i Turcja znajdzie się na prostszej linii rozwoju społecznego niż np. Polska czy Węgry. Sytuację te można wytłumaczyć tylko zahamowaniem rozwoju w następstwie wstrząsów historycznych ${ }^{5}$.

Teza Bibó jest następująca. Trzy historyczne kraje środkowoeuropejskie - Polska, Czechy, Węgry - w pierwszych wiekach kształtowania swych państwowości podążały krok w krok za zachodnimi sąsiadami i dopiero w wiekach XVI-XVIII, gdy spadła na nie seria katastrof, zostały zmuszone do porzucenia wyłącznie zachodniego modelu, na rzecz modelu hybrydowego - częściowo starego a częściowo nowego, wschodniego ${ }^{6}$. Miało to zasadniczy wpływ na charakter ich polityki w przyszłości, zwłaszcza w stuleciach XIX i XX. W tym okresie Węgry miały więcej „okazji” od swych sąsiadów, by powrócić na zachodnią ścieżkę rozwoju. I jak się przekonamy, ich niewykorzystanie najbardziej oddaliło właśnie ten kraj od zachodnich ideałów wolnościowych.

Bibó lubił podkreślać, że Węgry realizowały jedynie „prostszy i bardziej prowincjonalny charakter"7 zachodniego rozwoju. Przykładowo, węgierska Złota Bulla z 1222 roku powstawała zapewne pod wpływem angielskiej Wielkiej Karty Swobód z 1215 roku. Jednak nie ujrzałaby światła dziennego, gdyby wcześniej nie zaszły w węgierskim społeczeństwie wewnętrzne przemiany przygotowujące grunt pod powstanie

\footnotetext{
5 Idem, Nędza matych państw wschodnioeuropejskich, [w:] idem, Eseje polityczne, s. 51.

6 Idem, A magyar társadalomfejlödés és..., s. 494.

7 Ibidem, s. 495.
} 
tego dokumentu. Inny przykład podaje w eseju „O węgierskiej administracji”, gdzie wyróżnia trzy etapy jej kształtowania się. W wiekach XIII-XV na Wielkiej Nizinie (Alföld) powstał za sprawą niezepsutej jeszcze węgierskiej szlachty system zarządzania miastami węgierskimi ${ }^{8}$. Jego zadaniem było osiągnięcie takiego stopnia zróżnicowania fachowego (tak jak w owym czasie w Europie Zachodniej), który umożliwiał utrzymywanie działającego tu samorządu w bliskiej więzi z codziennymi potrzebami ludzi danej wspólnoty. I choć nie była to forma administrowania w pełni węgierska, bo kształtowała się pod wpływem administracji zachodniej, to udało jej się zachować do pewnego stopnia własne cechy. System ten wkrótce ustąpił miejsca systemowi zarządzania szlachty komitackiej. W wiekach XV-XVI wraz ze wzrostem potęgi wielkich obszarników ta niegdyś wewnątrz-szlachecka administracja stawała się narzędziem sprawowania władzy nad chłopami. Zamiast szlacheckiego samorządu powstała więc nastawiona na całkowite podporządkowanie chłopów interesom szlachty nowa forma administracji. Dlatego chłopi nie mieli możliwości stawiania szlachcie żądań wspieranych przez jakąś formę instytucjonalnego nacisku. Bibó tak charakteryzuje trzeci etap kształtowania się węgierskiej administracji:

Tak powstała dziwna kombinacja fachowego administrowania i surowej praktyki władzy, która szlachcie zapewniała korzyści płynące z fachowego pogłębienia oraz z codzienności, a jednocześnie korzyści czerpane z nagiej, praktycznej władzy poprzez skuteczne podporządkowanie sobie chłopów 9 .

\section{Podobnie rzecz ujmuje László Lakatos:}

Dominacja prywatnych interesów ośrodków władzy blokowała powstanie silnych, samodzielnych grup zawodowych i stąd słabe, o niepewnym statusie zawody nie umiały się rozwinąć do tego stopnia, by złamać dominację surowych, politycznych względów ${ }^{10}$.

Tezie o równoczesności rozwojowej Wschodu i Zachodu przeciwstawił się węgierski historyk i uczeń Bibó, Jenő Szücs. W eseju Trzy Europy - dedykowanym pamięci mistrza - podejmuje tę samą tematykę, lecz dochodzi do odmiennych wniosków. Czy rzeczywiście wystarczy powiedzieć, że węgierski feudalizm miał jedynie „bardziej prowincjonalny charakter", a w zasadzie nie różnił się od zachodniego? Według Szücsa różnica ta dotyczyła samej istoty feudalizmu, czyli roli państwa oraz podstawowej instytucji tego systemu - lenna. Procesy społeczne, które kształtowały Zachód przez pięć wieków, zostały przeniesione na grunt wschodni w ciągu zaledwie półtora wieku. Tak szybko nie można było zbudować zrębów społeczeństwa feudalnego na wzór

8 Idem, A magyar közigazgatásról (O węgierskiej administracji, tłum. - F.T.), [w:] idem, Válogatott tanulmányok..., s. 479.

9 Ibidem, s. 477.

10 L. Lakatos, Hajnal István hatása (tłum. - F.T.), (Wpływ Istvána Hajnala), [w:] A hatalom humánizálasa, ed. I. Z. Dénes, Pécs 1993. 
zachodni. Można je było tylko naśladować, imitować. Średniowieczne społeczeństwo zachodnie zostało ukształtowane najpierw przez feudalizm, a następnie przez system stanowy. Na Węgrzech próbowano równocześnie przenieść formy organizacji zasadnicze dla obu faz rozwojowych ${ }^{11}$. W efekcie węgierska wersja feudalizmu - familiaritas - była pozbawiona tego, co miało największe znaczenie praktyczne i symboliczne na Zachodzie, czyli lenna. Nie mogła też ukształtować się tu organiczna i autochtoniczna kultura rycerska. W niepełnym, niedokończonym feudalizmie węgierskim widzi Szűcs źródło przyszłego permanentnego kryzysu państw środkowoeuropejskich.

\section{Trzy katastrofy}

Z kolei dla Bibó pierwszym tragicznym zwrotem w historii Węgier, który zapoczątkował odchodzenie od zachodniej ścieżki rozwoju, było stłumienie powstania Dózsy w 1514 roku. W społeczeństwach zachodnich nawet krwawo stłumione powstanie dalej oddziaływało w kierunku dalszego zwiększenia wolności. Dlaczego w tym przypadku tak się nie stało? Z dwóch powodów. Za sprawą Istvána Werbőczyego, rzecznika interesów średniej szlachty, powstanie zbiegło się z rozbudzeniem politycznej świadomości tej warstwy. Główną myślą przewodnią jego dzieła - Tripartitum - było zrównanie w prawach niższej i wyższej szlachty. Nie oznaczało to jednak demokratycznej równości całego stanu szlacheckiego, lecz wspólnotę interesów skierowaną przeciwko chłopom. Król nie mógł odtąd samodzielnie wydawać ustaw i sprawować władzy bez zgody „narodu”. Wedle wyrażenia Werbőczyego, to szlachta była wcieleniem populus wobec prawa, niemożliwa więc była nawet teoretycznie odpowiedzialność króla przed abstrakcyjnym wprawdzie, ale całym społeczeństwem. $\mathrm{Na}$ Węgrzech (4-5\%), a zwłaszcza w Polsce (7-8\%) społeczeństwo szlacheckie przybrało w tym czasie olbrzymie rozmiary: „Na Węgrzech pod koniec średniowiecza jedna osoba na dwadzieścia lub dwadzieścia pięć należała do warstwy szlacheckiej. We Francji w tym samym czasie - jedna na sto. Na Węgrzech jedna osoba na czterdzieści była człowiekiem wolnym, we Francji - jedna na dziesięć”12. „Naród” tworzyła głównie drobna szlachta, którą Bibó, a za nim Szücs, nazywał „najbardziej szkodliwym zjawiskiem w rozwoju społecznym Węgier w epoce nowożytnej"13. Dzieło Werbőczyego dało początek zjawisku „drobnego szlachcica przepełnionego nienawiścią do chłopa” i stało się „złotą księgą” średniej szlachty węgierskiej na kolejne cztery stulecia. Tripartitum, łącząc jej małe wolności nie z małymi wolnościami mieszczan i chłopów, ale z dużymi wolnościami ziemiaństwa, na stałe wbiło klin pomiędzy węgierskie społeczeństwo a europejski rozwój.

Impas spowodowany przez stłumienie powstania Dózsy polegał również na tym, że nastąpiły po nim kolejne dwie katastrofy: wielka klęska pod Mohaczem w 1526

11 I. Kemény, Magyarság és Európa (tłum. - F.T.), (Węgierskość i Europa), [w:] A hatalom humánizálasa.

12 J. Szücs, Trzy Europy, Lublin 1993, s. 69.

13 Ibidem. 
roku, a przede wszystkim początek panowania na Węgrzech Habsburgów. Odtąd ośrodek węgierskiej władzy centralnej znajdował się za granicą - w Wiedniu, a państwo węgierskie zepchnięte zostało do roli drugorzędnej. Habsburgowie od początku do końca rządzili Węgrami z zewnątrz. Bibó tak to ujmuje:

W Wiedniu i w Pradze Habsburgowie czuli się u siebie, i w krajach tych lepiej lub gorzej wypełniali to zadanie, które w czasach nowożytnych należało do władzy królewskiej: powstrzymywali zapędy arystokracji, popierali mieszczaństwo, i bronili chłopów. Granice Węgier zaś były dla nich zewnętrzną linią obronną, gdzie nie prowadzono intensywnej pracy na rzecz rozwoju społecznego, ale wyłącznie imperialną i militarną politykę ${ }^{14}$.

Przez Węgry nie przechodziły już - jak dawniej - wielkie szlaki handlowe, nie było też silnego mieszczaństwa. Stąd pewien paradoks, na który Bibó zwraca uwagę:

Jakkolwiek dziwnie może zabrzmieć twierdzenie, że fakt uczynienia z zachodnioeuropejskiej dynastii - i to dynastii o poważnych tradycjach - władzy zwierzchniej we własnym kraju wciągnął go na drogę rozwoju społecznego opartego na sztywnym podporządkowaniu [pana i chłopa - F.T.], to jednak tak się właśnie stało, i było to zupełnie naturalne ${ }^{15}$.

Od 1514 roku zdarzały się oczywiście próby wyjścia z tej ślepej uliczki, lecz zawsze kończyły się niepowodzeniem i wręcz umocnieniem starego układu sił, podczas gdy zachodni układ społeczny nieustannie zmieniał się. Nadal na Węgrzech toczyły się konflikty między dynastią a magnaterią, które czasem prowadziły do zahamowania politycznych dążeń tej drugiej. Jednak po upadku powstania księcia Ferenca Rákócziego w pierwszej dekadzie XVIII wieku węgierska arystokracja na długie lata związała się z Wiedniem z wdzięczności za uratowanie przed całkowitą utratą prestiżu. Ta sama arystokracja ulegała stopniowo wynarodowieniu, widocznemu w przejmowaniu obcego języka i obyczajów.

\section{Narodziny nowoczesnego narodu}

Fundamentalnym wydarzeniem w ogólnoeuropejskim rozwoju społecznym, które sprawiło, że sprawy demokratyzmu i nacjonalizmu połączyły się we wspólnym dążeniu, była Wielka Rewolucja Francuska. W jakich okolicznościach dojrzewała do wybuchu? W wiekach XVI-XVIII na Zachodzie życiem politycznym narodu kieruje władza centralna, a świadomość narodowa staje się stopniowo atrybutem mieszczaństwa i inteligencji. Państwo tworzy jedność polityczną, prawną, administracyjną i gospodarczą, z centralnym ośrodkiem w stolicy. I wtedy społeczeństwo, które żyło wprawdzie w dobrobycie, ale w poczuciu braku fundamentalnych wol-

14 I. Bibó, A magyar társadalomfejlődés és..., s. 498.

15 Ibidem. 
ności, podejmuje próbę przeciwstawienia się absolutyzmowi. Wybucha rewolucja, która kładzie podwaliny pod kształtowanie się współczesnych narodów. Istotę tego procesu tak oto opisuje Bibó:

ramy istniejących już - bądź dopiero tworzących się - narodów zaczynają być wypełniane wielkimi ruchami masowymi, przy czym uczucia, łączące się z pojęciem narodu, są zawłaszczane przez potężną i powszechną uczuciowośćc ${ }^{16}$.

Akcent pada tu na „ruchy masowe i uczucia powszechne”, ponieważ na arenę europejskiej polityki wkroczył stan trzeci. Były to przede wszystkim mieszczaństwo i inteligencja, które

biorą w posiadanie i czynią własnym kraj królów i szlachty z całym jego historycznym prestiżem, z jego reprezentacyjną, wyzywającą samoświadomością, ale jednocześnie pogłębiają go ciepłymi, bezpośrednimi uczuciami, którymi dotychczas obdarzały swoje małe wspólnoty ${ }^{17}$.

Idee rewolucji francuskiej, formujące nowoczesne narody, dotarły także do krajów Europy Środkowo-Wschodniej. W Polsce proces budowania nowoczesnego narodu rozpoczął się w latach 1772-1794. Węgrzy przystąpili do pracy później - w latach 1825-1848, które przeszły do ich historii jako „Okres reform”. Był to według Bibó największy wysiłek narodu węgierskiego na drodze do osiągnięcia zachodniego poziomu rozwoju społecznego - jedna z nielicznych okazji, gdy okoliczności historyczne stworzyły szansę wspólnego działania chłopów, szlachty i magnaterii. Polacy i Węgrzy przystąpili do wielkiego reformatorskiego dzieła $\mathrm{z}$ wielkim entuzjazmem. Niestety ani jednym, ani drugim nie było dane go ukończyć.

Kwestia nie-madziarskich narodowości (Chorwaci, Rumuni, Serbowie, Słowacy) zamieszkujących historyczne Węgry jest niezwykle istotna do zrozumienia tragedii narodu węgierskiego w XIX i XX wieku. Postępowi, radykalni i przesiąknięci oświeceniowymi ideałami politycy węgierscy nie dopuszczali nawet myśli o przyciągnięciu do siebie nie-madziarskich ruchów narodowych właśnie wtedy, gdy zaistniała po raz ostatni w historii ich koegzystencji możliwość porozumienia się. Wielonarodowościowe Węgry postawiły sobie za cel stworzenie państwa narodowego, z jednym językiem urzędowym. Bibó twierdzi, że nacjonalizm językowy nie ukształtowałby się, gdyby genezę nowoczesnego narodu sprowadzić do teorii, według której ludzie mówiący tym samym językiem „zbierają się”, by stworzyć wspólnotę. Problem w tym, że naród powstaje na drodze politycznej, nie językowej. W wyniku historycznych procesów i przeżyć zbiorowych kształtuje się pamięć historyczna, która jest przepełniona uczuciami związanymi z przeszłością narodu ${ }^{18}$.

16 I. Bibó, Nędza małych państw wschodnioeuropejskich, s. 27.

17 Ibidem, s. 31.

18 Ibidem, s. 35. 
Gdy więc w latach 1825-1848 uczucia narodowe są zawłaszczane przez węgierskie społeczeństwo, podobne procesy zachodzą w świadomości narodów nie-madziarskich wchodzących w skład Korony. Wytwarzają własną inteligencję, coraz bardziej świadomą swej odrębności etnicznej i dążącą do przekształcenia swych społeczności w odrębne narody. A jednocześnie szukają poza granicami Węgier pobratymców, by się z nimi połączyć. Kardynalnym błędem węgierskiej warstwy przywódczej była wiara, że demokratyzacja przyniesie jedność narodową w ramach historycznych Węgier:

Nadzieja ta okazała się iluzją, w 1848 roku naród węgierski, rzuciwszy się z ogromnym entuzjazmem do walki o wyzwolenie się spod panowania Habsburgów, spostrzegł na przeciw siebie innojęzyczne narodowości zamieszkałe na terytorium Węgier. Byli to przede wszystkim Chorwaci, Serbowie i Rumuni, których separatystycznych dążeń Węgrzy nie byli w stanie uznać. W ten sposób walczące o wolność Węgry stanęły oko w oko z siłami europejskiej reakcji i jednocześnie z własnymi niezadowolonymi narodowościami, a skutkiem tego była katastrofa 1849 roku $^{19}$.

Następstwa stłumionej przez połączone siły austriacko-rosyjskie węgierskiej rewolucji 1948 roku były dla Węgrów fatalne. W węgierskiej warstwie rządzącej utwierdziły się na stałe dwa przekonania. Po pierwsze, w walce o niepodległość Europa zostawiła ich samych sobie. Po drugie, nie-madziarskie narodowości wykorzystują swobody demokratyczne do oderwania się od Węgier. Wnioski wyciągnięte z tych dwóch - słusznych zresztą - przesłanek doprowadziły do szeregu dalszych impasów $\mathrm{w}$ rozwoju społecznym i politycznym. Chęć zatrzymania za wszelką cenę Węgier $\mathrm{w}$ ich historycznych ramach oraz poczucie opuszczenia przez Europę w czasie rewolucji doprowadziły do pierwszej wielkiej ,ślepej uliczki” (wszystkie następne Bibó sprowadzał właśnie do tej jednej) we współczesnej historii Węgier, czyli do ugody austriacko-węgierskiej z 1867 roku. Jej istotę Bibó widział w tym, że Węgrzy w celu utrzymania historycznych ram państwowych, zrezygnowali z pełnej niepodległości.

W eseju Wypaczony charakter wegierski i sprzeczna historia Węgier Bibó szuka odpowiedzi na pytanie współczesnego mu pisarza László Németha - „Gdzie zatracił się w Węgrze węgierski duch?”20. Trop Németha prowadzi go do zjawiska XIX-wiecznej asymilacji mniejszości narodowych, niemieckiej i żydowskiej. Inni doszukiwali się źródła choroby „węgierskiego ducha” w obcych wpływach, niemieckim kolonializmie i w obcej władzy. Bibó przyznając im rację w szczegółach, nie podziela żadnego z tych poglądów i wybiera własną drogę. Sięga wstecz, do lat 60 . XIX wieku i tłumaczy, dlaczego właśnie tam:

W dobie absolutyzmu sytuacja polityczna narodu była sprawą czystą. Stękał pod dyktatem tyranii, w dodatku tyranii obcojęzycznej, zbiurokratyzowanej i małostkowej,

19 I. Bibó, Eltorzult magyar alkat, zsákutcas magyar törtenelem (Zniekształcony charakter węgierski i sprzeczna historia Węgier, tłum. J. Snopek), [w:] idem, Válogatott tanulmányok..., s. 578.

20 Ibidem, s. 573. 
przyjął postawę biernego oporu. Jednak po dziesięciu latach takiego oporu na płaszczyźnie rozwoju społecznego Węgier ujawnia się fatalny proces: erozja inteligencji i postępowej średniej szlachty ${ }^{21}$.

Narodowa inteligencja pod wpływem klęski rewolucyjnej straciła chęć do działania i coraz bardziej pragnęła bezpieczeństwa. Tym samym uniemożliwiła części szlachty oddanie się sprawie postępu.

W obojętności, jaka ogarnęła te grupy, Bibó doszukiwał się głównego czynnika sprawczego austriacko-węgierskiej ugody. Jako jej pierwszy filar wymienia wzajemne przecenianie aktualnej pozycji międzynarodowej obu państw ${ }^{22}$. Austriacy „wybrali” Węgrów, bo pokazali się jako naród najgroźniejszy, najbardziej prący do niepodległości. Ale od czasu rewolucji 1948 roku, w ciągu 18 lat, zaszła w społeczeństwie węgierskim zasadnicza zmiana postaw w warstwach potencjalnie rewolucyjnych. Potencjalnie, bo nie wolno zapominać, że społeczeństwo to było zdeformowane z powodu braku silnej warstwy mieszczańskiej, która na Zachodzie była główną siłą rewolucyjną. Na podobnej zasadzie Węgrzy przekonali się do ugody, sądząc, że imperium Habsburgów to stały element europejskiego systemu państw. Fałszywe myślenie było nieuniknione, bo żaden z narodów sam nie utrzymałby się w tym systemie. Węgrzy i Austriacy umówili się, że wspólnie będą chronić to, co dla nich najcenniejsze, jedni - historycznego państwa, inni - swego imperium.

Drugim filarem ugody był jej konserwatyzm. Mogła zostać zawarta tylko w latach 1867-1877, kiedy to konserwatyści ustąpili na chwilę miejsca liberałom. Nowy minister spraw zagranicznych Friedrich Beust po klęsce w wojnie z Prusami był świadom pogarszającej się koniunktury międzynarodowej i zainicjował wspólne rozmowy z delegacją węgierską w kwestii przyszłej umowy. Gdy już została zawarta, obwieszczono ją wielkim triumfem europejskich sił liberalnych. Dla węgierskich liberałów punktem wyjścia były - lub powinny były być - osiągnięcia 1848 roku, czyli znaczna autonomia i ustrój liberalno-konstytucyjny. Zaczął ich jednak paraliżować lęk przed wyjściem Austrii z dualizmu na skutek wysunięcia węgierskich żądań i w efekcie nie podjęto żadnych poważnych reform. Ugoda austriacko-węgierska była zbudowana na strachu i chęci utrzymania status quo, a nie na aktywnych planach i celach.

Wreszcie trzecim filarem całej konstrukcji był jej fałsz. Okłamywała w równym stopniu obie strony. Habsburgów łudziła, że jej potęga przetrwała. Tymczasem w samym sercu monarchii znajdowało się państwo, w którym klasa polityczna była wyraźnie podzielona w sprawie lojalności wobec dynastii i już ten fakt uniemożliwiał proces integracji. Po drugie austriaccy Niemcy stracili ostatnie nadzieje, że habsburska Austria stanie na czele wielkiego dzieła zjednoczenia Niemiec. Trzecim ciosem było odrzucenie przez węgierskiego ministra spraw zagranicznych monarchii Gyulę Andrássyego czeskich żądań uzyskania statusu równego Węgrom. Tak Austriacy zyskali sobie kolejnego wewnętrznego wroga.

21 Ibidem, s. 580.

22 Ibidem, s. 583. 
Przede wszystkim jednak ugoda została zawarta, bo węgierska klasa polityczna po raz pierwszy w swej historii zaczęła kierować się w polityce strachem - co stanie się odtąd jej nieodłącznym atrybutem - a nie zdrowym wyczuciem sytuacji. Węgrzy przyjęli założenia, które były ze sobą sprzeczne. Jako pierwsze wymienia Bibó chęć odzyskania niepodległego państwa węgierskiego z własną konstytucją. Drugą było przekonanie, że bliższym im ustrojem jest monarchia konstytucyjna niż republika. Trzecią wytyczną było zachowanie historycznych ram państwowych. Jednak wszystkie trzy nie mogły być zrealizowane jednocześnie, bo dwie ostatnie były sprzeczne z pierwszą ${ }^{23}$. Niepodległy charakter państwa kłóci się z instytucją monarchii konstytucyjnej. Ta w swej XIX-wiecznej wersji utożsamiała się z jednym tylko narodem. Imperium Habsburgów zaś składało się z pięciu narodów historycznych oraz sześciu prących do niepodległości grup etnicznych. Z kolei chęć zachowania historycznego państwa była sprzeczna $z$ dążeniem do wolności i konstytucyjności, czyli niepodległości.

Diagnoza Bibó jest jednoznaczna - ugoda austro-węgierska pokazała, że Węgrzy na dobre zatracili swój instynkt narodowy ${ }^{24}$. Misją ukształtowanej w okresie reform 1825-1848 nowej klasy politycznej miało być przeprowadzenie rewolucji, która przyniosłaby Węgrom niepodległość - lub bardzo szeroką autonomię - oraz nowy antyfeudalny ustrój społeczny. Ta ukształtowana na wzór europejski elita będąca jedynym czynnikiem postępu, uległa w latach 60 . XIX wieku demoralizacji i z czasem została zdominowana przez żyjące w ciągłym strachu węgierskie siły reakcyjne. Węgierscy liberałowie i główni twórcy ugody: Ferenc Deák, Zsigmond Kemény czy József Eötvös, byli w oczach Bibó politykami wybitnymi. Ale porzucili dawne patriotyczne ideały i poddali się reakcji. A jeśli nie prowadzi się polityki zgodnej ze swymi prawdziwymi interesami, to pozostaje tylko ucieczka w kłamstwo:

Jest to klasyczny przykład tego, w jaki sposób mechanizm rozumu zostaje w polityce zniewolony przez mechanizm strachu (...) Musimy wbrew rozpowszechnionym poglądom podkreślić, że w polityce nie można kłamać. Ściślej mówiąc, można tu i tam posłużyć się jakimś kłamstewkiem, ale na kłamstwie nie sposób budować politycznego programu. Dalszy los ugody pokazuje ze szczególną wyrazistością, że kłamstwa w polityce zawsze się mszczą ${ }^{25}$.

Wszystkie troski i lęki, jakie stały się udziałem węgierskiej klasy politycznej na kolejne pół wieku, kazały jej uznać to, co stworzyła ugoda, za niepodległość. Każdy węgierski rząd w okresie 1867-1918 uciekał od rozwiązania kwestii narodowościowej, żeby uniknąć groźby rozpadu historycznych Węgier. W rezultacie strach ten sprowadził na nich katastrofę jeszcze większą od dotychczasowych. W myśl postanowień traktatu pokojowego w Trianon z 1920 roku, Węgry na rzecz państw ościennych straciły nie-

23 Ibidem, s. 588.

24 Ibidem.

25 Ibidem, s. 590. 
mal trzy-czwarte swego terytorium i ponad dwie-trzecie ludności. W tym - i to było dla nich najsurowszą „karą” - jedną-trzecią ludności rdzennie węgierskiej.

Węgrzy odwracali się od demokracji i od Europy. Ich tok rozumowania był następujący. To demokratyczne prawo do samostanowienia rozbiło ich historyczne państwo. Co więcej, podzieliło naród węgierski na obywateli lepszej i gorszej kategorii, jako że ci drudzy zostali oderwani od swych rodaków. W polityce wewnętrznej upadek obu rewolucji - mieszczańskiej Mihálya Károlyiego (1918) i proletariackiej Béli Kuna (1919) - umocnił tylko społeczeństwo węgierskie w niechęci i do demokracji, i do socjalizmu. Nowy przywódca Węgier Miklós Horthy, rządzący w latach 1920-1944, używał więc kwestii narodowościowej jako społecznej legitymizacji sprawowania władzy. Druga naczelna zasada, którą się kierował, to reakcjonizm, który przejawiał się we wspólnym froncie, jaki „klasa panów” z klasą mieszczańską utworzyły przeciw klasom najniższym: chłopom i robotnikom.

Tak oto dwudziestoletni okres rządów kontrrewolucyjnych admirała Horthyego opisuje badacz współczesnej historii Węgier Rudolf L. Tökés: „Były one określane różnie - jako konserwatywne, chrześcijańskie, autorytarne lub faszystowskie. Pierwsze trzy z tych określeń są adekwatne do tamtej epoki, natomiast czwarte nie jest”26. Bibó widział tamten okres w ciemniejszych barwach: „Wyłoniła się polityczna konstrukcja kontrrewolucji, która już z całą ostrością formułowała i uznawała wzajemne powiązania nacjonalizmu i antysemityzmu $z$ jednej strony, a demokratyzmu, beznarodowości i syjonizmu - z drugiej"27. Wydaje się, że Tökés ma rację tylko częściowo, bo w okresie Horthyego kierunek polityki nie był jednolity. Rządy zmieniały się, a wraz z nimi rozkład akcentów w polityce zagranicznej i wewnętrznej. Od 1933 roku sytuacja w kraju zmierza w groźnym kierunku i autorytaryzm ustępuje miejsca faszyzmowi. Do pełnej faszyzacji kraju dochodzi w marcu 1944 roku, gdy wojska Hitlera wkraczają na Węgry, a nowy premier Ferenc Szálasi rozpętuje straszliwy terror przy pomocy oddziałów „strzałokrzyżowcow” (nyilaskeresztesek).

\section{Nędza małych państw środkowoeuropejskich}

Jaki oddźwięk znalazły ideały Wielkiej Rewolucji Francuskiej w innych krajach środkowoeuropejskich? Czy tam także zmieniły się we własne zaprzeczenie? Otóż diagnoza, jaką całemu regionowi stawia István Bibó, należy chyba do najbardziej pesymistycznych $w$ literaturze przedmiotu. Antydemokratyczny nacjonalizm był tak rozpowszechniony w tej części Europy, że w celu opisania tutejszych zjawisk społeczno-politycznych Bibó odwoływał się do terminologii klinicznej. Pisał o równowadze i paraliżu międzynarodowej wspólnoty, o chorobie ówczesnych czasów i lekarstwach na nią; sam więc doczekał się miana politycznego diagnostyka, a nawet psychoanalityka. Jego najsłynniejszy esej - Nędza małych państw wschodnioeuropejskich (1946) - to oryginalna genealogia „wspólnotowych histerii” państw tego regionu.

26 B. Góralczyk, Węgierski pakiet, Warszawa 2000, s. 7.

27 I. Bibó, Kwestia żydowska, [w:] idem, Eseje polityczne, s. 415. 
Kształtowanie się nowoczesnego narodu nie wszędzie wyglądało tak samo, a proces ten sam w sobie nie jest czymś jednoznacznie pozytywnym. Przeobrażenia dokonywały się w jednych narodach dość łagodnie, w innych gwałtownie, w jeszcze innych pod postacią serii kryzysów. W Europie Zachodniej i Północnej lud wiedział, jaką sferę państwową ma zawłaszczyć - oczywiście tę aktualnie istniejącą. W Europie Środkowo-Wschodniej sytuacja była bardziej skomplikowana. Na początku XIX wieku kształtujące się narody tego regionu również wiązały przyszłą sferę państwową z istniejącymi obecnie historycznymi ramami narodowymi. Problem jednak stanowiło wydostanie się spod jarzma obcej, narzuconej władzy. Gdy to się wreszcie udało, narody te stanęly przed kolejnym wyzwaniem - faktem braku legitymizacji państwowej. Okazało się, że nie mają własnego aparatu państwowego, kultury politycznej, elity narodowej, nawet stolicy. Wszystkie te niezbędne wyznaczniki państwowości miały kraje zachodnie, a także imperium Habsburgów. Zwłaszcza narody wchodzące w skład tego „hybrydowego tworu” usilnie chciały wykazać, że są historycznie głębiej zakorzenione i bardziej zdolne do samodzielnego życia niż imperium.

W związku z tym zwrócono się ku „ludowi” i tak odkryta została nowa, potężna siła społeczna, która nie miała swojego odpowiednika w zachodniej części Europy:

Lud, który w Europie Zachodniej reprezentował po prostu dynamikę wzrostu społecznego (peuple), stał się w Europie Środkowej i Wschodniej głównym nosicielem swoistych sit narodowych (volk) - odpowiadającym lepiej niż nieczyste etnicznie i kulturowo warstwy wyższe - „prawdziwym” kryteriom przynależności do narodu (język, zwyczaje ludowe itd.) $^{28}$.

Za sprawą ludu powstało nowe zjawisko specyficznie środkowoeuropejskie nacjonalizm językowy. To właśnie ono sprawiło, że Węgrzy czy Polacy nie mogli poprzestać na historycznych strukturach państwowych, bo zaczęli patrzeć na własną sytuację przez pryzmat językowego układu sił. Trzeba było stworzyć terytorialne ramy narodowe i ramy państwowe, a następnie umocnić je i przygotować się do ich obrony. Pamięć historyczna tutejszych narodów wiązała je bowiem z terytoriami większymi od tych, które zamieszkiwały, a także ze znajdującymi się tam miastami, pamiątkami historycznymi i lokalnymi wartościami. Prowadziło to w rezultacie do licznych sporów terytorialnych, które nieustannie przeradzały się w wojny.

W tym tkwi źródło zachwiania równowagi między dwoma komponentami nowoczesnego uczucia narodowego. We wzajemnym związku uczuć narodowych i demokratycznych na Zachodzie silniejsze były uczucia obywatelskie, uczucia mieszczanina będącego symbolem demokracji, jako że bliższy jej jest sposób życia oparty na „staranności i pracowitości”. W Europie Środkowej zdecydowanie silniejszy akcent padł na uczucia narodowe. Dla stworzenia nowych ram narodowych trzeba było zakwestionować istnienie aktualnego systemu państw europejskich. Okoliczności

28 Idem, Nędza małych państw wschodnioeuropejskich, s. 35. 
te wywindowały do władzy trzy specyficzne siły, które odtąd na stałe zdominowały scenę polityczną w tych krajach: sojusz władcy, szlachcica i żołnierza. Przejąwszy władzę na podstawie narodowej, mogli bez trudu tłumić siły demokratyczne. Jednak to nie ich interesy sprowadziły na tę część Europy nacjonalizm. Powstał on za sprawą demokratyzacji uczuć narodowych. Mogą one wypływać jedynie z emocji, emocje zaś z rzeczywistych przeżyć, a więc z historycznych wstrząsów. To one zakłóciły równowagę i rozwój tej części Europy. Olbrzymiego wysiłku podjęła się inteligencja. Na nowo odkrywała odrębność i swoistość narodową, aby uświadomić szerokim rzeszom społeczeństwa, że to one, siły ludowe, są właściwym nośnikiem historyczności narodu, a nie rządzące warstwy polityczne.

Świadomość narodowa w społeczeństwach zachodnich budzi się tylko w sytuacjach krytycznych. Ponieważ obecna jest cały czas, nie potrzebuje nieustannego samopotwierdzenia. Tymczasem „małe państwa wschodnioeuropejskie” posiadały terytoria, o których los obawiały się z racji tego, że znajdowały się przez kilka wieków pod obcym panowaniem. A w sytuacjach ekstremalnych stawały wręcz twarzą $\mathrm{w}$ twarz z groźbą zagłady. Te zasadnicze różnice $\mathrm{w}$ doświadczeniu historycznym narodów zachodnio- i wschodnioeuropejskich tak oddaje Bibó:

Zachodni Europejczyk może sobie wyobrazić eksterminację, zniewolenie lub stopniową asymilację, ale dokonujące się z dnia na dzień polityczne unicestwienie jest dla niego jedynie jakimś patetycznym widmem, podczas gdy dla narodów wschodnioeuropejskich jest twardą, namacalną realnością. Tu nie trzeba narodu mordować czy deportować, tu do tego, by poczuł się zagrożony starczy z wielkim zdecydowaniem i wielką agresją zakwestionować jego istnienie ${ }^{29}$.

Bibó zwraca uwagę na jeszcze jeden niezmiernie istotny aspekt nowoczesnego rozwoju politycznego. Chodzi o to, by sprawa wspólnoty i sprawa wolności stanowiły jedność. Demokratyzm i nacjonalizm mają bowiem wspólne korzenie. W krajach środkowowschodnich oba procesy nie zachodziły równolegle wskutek zachwiania równowagi miedzy uczuciami narodowymi i demokratycznymi. Tutejsze narody wręcz bały się wolności, a wraz z nią upadku dotychczasowych sił społecznych uciskających lud, bo wiedziały, czym to się może skończyć. W przypadku Węgrów - rozsadzeniem od wewnątrz ich historycznego państwa. Oznaczało to stopniowe podporządkowanie parlamentu głowie państwa. Władza osobista stawała się ostateczną instancją, od której lud oczekiwał poprawy swego położenia.

Tak właśnie za sprawą egzystencjalnego lęku przed demokracją, która zagrażała sprawie narodu, powstawał w Europie Środkowej antydemokratyczny nacjonalizm. Na pojęciu strachu zbudował Bibó swoją słynną definicję demokracji:

Być demokratą to przede wszystkim - nie bać się. Nie bać się ludzi o innych poglądach, ludzi mówiących innym językiem, ludzi innej rasy. Nie bać się rewolucji, spisków,

29 Ibidem, s. 54. 
ukrytych zamiarów przeciwnika, wrogiej propagandy, i wszystkich tych wyobrażonych zagrożeń, które stają się prawdziwym zagrożeniem właśnie przez to, że się ich boimy ${ }^{30}$.

Kraje środkowoeuropejskie żyły w strachu, bo nie były demokracjami i dlatego stale obawiały się tego, czego demokracje zachodnioeuropejskie bały się tylko w momentach krytycznych.

\section{Niemiecka histeria}

Antydemokratyczny nacjonalizm prowadzi w prostej linii do wspólnotowej histerii. Jej źródłem są zawsze wstrząsające doświadczenia polityczne, które jawią się wspólnocie jako niemożliwe do zniesienia, będące ponad jej siły i przestaje być ona zdolna do samodzielnego rozwiązywania dalszych problemów. Ucieka więc w rozwiązania pozorne i zaczyna postrzegać rzeczywistość w sposób fałszywy. Wspólnoty politycznie zrównoważone umieją odszukać źródło problemu i je zlikwidować, ponieważ kierują się zdrowym instynktem, czyli jasną świadomością własnego interesu i mocnym zakotwiczeniem w aktualnej rzeczywistości. Zdrowa wspólnota - tak jak zdrowa jednostka - „znosi to, co ocenia jako nieuniknione fatum, przyjmuje odpowiedzialność moralną za to, co może przypisać własnym wadom czy błędom, przechodzi do porządku dziennego nad tym, na co nie ma wpływu, wyrzeka się marzeń nie dających się urzeczywistnić oraz określa i rozwiązuje stojące przed nią zadania" 31 .

Histeria może narastać przez kilka pokoleń. Tak właśnie było w przypadku Niemiec i tam osiągnęła ona swój punkt szczytowy. Bibó pisze w eseju Dzieje i przyczyny niemieckiej histerii politycznej, że wielki paradoks i wielkie nieszczęście w historii tego narodu polegały na tym, że choć należał geograficznie w całości do obszaru zachodniego rozwoju społecznego, to niemiecki ustrój społeczny znacznie odbiegał od zachodnich sąsiadów. Ukształtowany w średniowieczu system księstw terytorialnych zachował się tam jeszcze w XX wieku. To ta instytucja odgrywa według Bibó kluczową rolę w zrozumieniu dziejów Niemiec. Skostniała niemiecka struktura polityczna oparta na prymacie księstwa terytorialnego nad władzą centralną i nad mieszczaństwem zatrzymała nie tylko rozwój polityczny Niemiec. Stanęła też na drodze niezakłóconemu przepływowi na Wschód zachodnich struktur. Dlatego historia Czech, Polski i Węgier jest w dużej mierze określona przez próby umocnienia ich przynależności do Zachodu oraz usunięcia stojących im na drodze politycznych i społecznych wpływów Niemiec.

Najnowsza historia Niemiec to szereg pięciu następujących po sobie sytuacji politycznych: Święte Cesarstwo Rzymskie Narodu Niemieckiego, Związek Niemiecki, Cesarstwo Niemieckie, Republika Weimarska, Trzecia Rzesza ${ }^{32}$. Każda w swym cho-

30 Ibidem, s. 56.

31 Idem, Dzieje i przyczyny niemieckiej histerii politycznej, [w:] idem, Eseje polityczne, s. 110.

32 Ibidem, s. 115. 
robliwym stanie była naturalną konsekwencją poprzedniej. Histeria wspólnotowa dojrzewa w kilku etapach: najpierw następuje wstrząs polityczny, potem identyfikacja wroga, który w tym wstrząsie miał główny udział, dalej trzeba wybrać odpowiedni środek obrony własnej, wreszcie nadchodzi czas zadośćuczynienia, co prowadzi do apogeum danej histerii - megalomanii i utraty poczucia miary. Otóż wyjątkowość niemieckiej histerii widzi Bibó w tym, że cały ten łańcuch przyczynowo-skutkowy powtórzył się w przeciągu ponad wieku aż dwa razy, a jeden $\mathrm{z}$ drugim tworzą organiczną jedność. Pierwszy rozpoczął się wstrząsem pruskiej klęski pod Austerlitz w 1806 roku, w jego rezultacie głównym niemieckim wrogiem stali się Francuzi. Następnie powstało pozornie potężne Cesarstwo Niemieckie, które zemściło się na Francuzach, zadając im upokarzającą klęskę w 1871 roku. I wreszcie narodził się mit wielkiej militarnej potęgi pruskiej, który rozpłynął się wraz z przegraną wojną światową. Tu kończy się pierwsza histeria i zaczyna druga, która jednak znacznie szybciej dobiegnie kresu. Wielkim wstrząsem są postanowienia traktatu wersalskiego, które każą szukać śmiertelnego wroga odpowiedzialnego za to upokorzenie. Niemcy znajdują dwóch: Żydów i państwa Europy Zachodniej, czy może raczej ich ideowe podstawy. Zadośćuczynienie polega na rewizji traktatu wersalskiego, co nie pociąga początkowo za sobą żadnego niebezpieczeństwa. Niemcy więc militaryzują się i wkrótce dochodzi do Anschlussu Austrii. Wraz z atakiem na Polskę tracą poczucie rzeczywistości; w latach wojny histeria pogłębia się coraz bardziej, aż w końcu prowadzi do ostatecznej klęski.

Spróbujmy teraz w podobny sposób zrekonstruować dzieje węgierskiej histerii politycznej. Wstrząsającym doświadczeniem z pewnością był dla Węgrów udział nie-madziarskich narodowości w stłumieniu rewolucji 1848 roku. Musiało się to odbić ciężkim piętnem na psychice Węgrów. Odtąd za największe zagrożenie dla ich państwowego bytu będą uważać niepodległościowe dążenia tych narodowości. Środkiem obrony własnej i zarazem zadośćuczynieniem będzie ugoda z potężną monarchią Habsburgów. Kolejnym wstrząsem jest traktat w Trianon, który zostanie pomszczony dwoma arbitrażami wiedeńskimi, a nabytki terytorialne umocnią społeczeństwo w poczuciu własnej siły.

Wydaje się jednak, że nie trzeba węgierskiej histerii koniecznie śledzić powyższym tropem. Wystarczy stwierdzić, że w pewnym momencie społeczeństwo jako całość zupełnie się pogubiło na skutek utraty instynktu politycznego w węgierskich warstwach przywódczych. Do momentu krytycznego (albo ostatniego stadium histerii) doszło w marcu 1944 roku. Na skutek wykrycia spisku Horthyego z aliantami zachodnimi, Hitler decyduje się na okupację Węgier. I tu chyba najlepiej widać całkowite zatracenie zdrowego instynktu przywódców węgierskich. Bibó twierdzi, że z powodu braku ich reakcji, wtargnięcie wojsk hitlerowskich na Węgry dokonało się w atmosferze praworządności. Władze przeszły do porządku dziennego nad niemiecką okupacją, umacniając przyglądające się temu społeczeństwo w poczuciu naturalności tego, co się dzieje. W ten sposób Węgrzy przyzwyczajali się do otaczającego zła. Nastroje społeczne zmieniły się, gdy rozpoczęto deportację Żydów, ale 
„przy ówczesnym stopniu demoralizacji społeczeństwa, przy skutecznym niszczeniu w nim postaw heroicznych i zafałszowanym rozumieniu kwestii praworządności nie mogła zrodzić się świadoma i skoordynowana akcja pomocy"33.

Dlaczego węgierscy przywódcy polityczni nie zareagowali? Dlaczego w sytuacji ekstremalnej, gdy zła doświadczała fizycznie i na co dzień duża część węgierskich obywateli, nie byli oni w stanie mu się przeciwstawić? Bibó zwraca uwagę na irracjonalne przekonanie węgierskich elit o zagwarantowanym bezpieczeństwie dla narodu. Czyżby nie dopuszczali do wiadomości, że może ich czekać podobny los, jaki spotkał Żydów i Polaków? W końcu to historyczna ugoda z Austriakami po raz pierwszy doprowadziła węgierską inteligencję do przekonania, że spory natury prawnej mogą mieć Węgrzy tylko z Austriakami, a więc i Niemcy są ich sprzymierzeńcami.

\section{Wrodzone wady środkowoeuropejskiego rozwoju społecznego?}

Bibó daleki był od tego, by uważać społeczeństwo węgierskie za szczególnie podatne na impasy w rozwoju społecznym i politycznym. W przeciwnym razie znaczyłoby to, że jest ono niejako predestynowane, by rozwijać się bardziej tak, niż inaczej. Charakter narodu - podobnie jak jednostek - jest określany przez czynniki wrodzone, wpływy zewnętrzne oraz proces rozwoju ${ }^{34}$. A to oznacza, że nigdy nie jest określony do końca. Odwaga czy współczucie to nie cechy istniejące same w sobie; ujawniają się dopiero pod wpływem konkretnych okoliczności i u konkretnych osób. Bibó zwraca uwagę na ogromną rolę, jaką odgrywają w dziejach narodów autorytety. Możliwość ujawnienia się powyższych cnót zależy w dużej mierze od siły przebicia wielkich jednostek, od tego czy są one

zdolne wzbogacić pasją moralną brawurę ludzi pozornie odważnych, czy są zdolne zapewnić wahającym się ludziom dobrej woli oraz wszystkim nie dość śmiałym i nazbyt wygodnym atmosferę społecznej aprobaty i solidarności ${ }^{35}$.

Co $\mathrm{w}$ takim razie $\mathrm{z}$ całym bagażem historycznych doświadczeń - dziejowych impasów, politycznych katastrof, wspólnotowych histerii - które złożyły się na „nędzę państw środkowoeuropejskich”? Niewątpliwie nie da się ich wymazać. Ale wystarczy choćby jedno wydarzenie z przeszłości, które od nich odstaje, by móc z niego czerpać wzór i siłę do działania w przyszłości. Nie można stale trzymać się tych samych wytycznych tylko $\mathrm{z}$ racji tego, że tak się robiło od wieków. Zdrowy charakter ocenia się pod kątem zdolności adekwatnego reagowania do zmieniających się okoliczności i mierzenia sił na zamiary, a nie na odwrót. Dopóki naród istnieje, dopóty jego charakter nie może być ostatecznie określony. I dopiero sumę różnych możliwości realizowanych w dziejach narodu możemy nazwać jego charakterem.

33 Idem, Kwestia Żydowska, s. 330.

34 Idem, Eltorzult magyar alkat..., s. 615.

35 Idem, Kwestia żydowska, s. 326. 
Ale na tym musimy poprzestać, a zatem nie wolno nam dodawać do terminu „charakter” żadnych przymiotników. Z tego, że ktoś jest prawdziwym Węgrem - pisze Bibó - nie wynika, że tym samym musi być prawdziwszym Węgrem ${ }^{36}$.

Ani naród węgierski, ani niemiecki, ani żaden inny nie rozwija się w sposób konieczny według jakiegoś schematu, nie istnieją bowiem cechy ontologicznie przysługujące wspólnocie jako takiej. Deformacja ducha narodowego, a wraz z nią „histeria” narodu rodzi się z konkretnych przyczyn i uwarunkowań. Da się ją wyleczyć, gdy zajdą sprzyjające okoliczności. W eseju Wypaczony charakter węgierski i sprzeczna historia Wegier Bibó powołuje się na przykład społeczeństwa angielskiego i francuskiego, a nawet rosyjskiego, by pokazać, że wszystkie one w pewnym momencie poszły w kierunku przeciwnym od dotychczasowego ${ }^{37}$. Anglicy pod wpływem reformacji stworzyli własny kościół, który ukształtował specyficznie angielski purytanizm. Francuzi przeprowadzili rewolucję, która całkowicie zmieniła charakter ich państwa. Rosjanie natomiast od czasów wielkiego punktu zwrotnego, jakim była rewolucja październikowa, przez kolejne dekady mierzyli się z jej konsekwencjami. Wszystkie te wydarzenia odkształciły - sprawiającą dotąd wrażenie trwałej - duszę angielską, francuską i rosyjską.

Wydaje się, że dla Bibó podobnym przykładem dziejowej przemiany węgierskiego społeczeństwa mógłby być przełom roku 1945. Warto jednak spytać, czy sceptycyzm Jenő Szücsa, który pisał o sztucznym i gwałtownym charakterze, imitującego zachodni, feudalizmu środkowoeuropejskiego, nie byłby i w tej sytuacji uzasadniony? Biorąc pod uwagę dalsze konsekwencje tych przewrotów europejskich, nasuwa się również pytanie o rozróżnienie na rewolucje odgórne i oddolne - na te, w których zmian dokonuje się za pomocą państwowego przymusu oraz na zmiany wychodzące z samej spontanicznej woli narodu.

\section{Historia tworzy się na nowo i zatacza koło}

Jakie było znaczenie i sens „wyzwolenia”? Związek Radziecki wyzwolił wprawdzie kraje wschodnioeuropejskie od okupacji hitlerowskiej, ale w jej miejsce powołał nowy porządek polityczny, który z czasem nabierał cech totalitarnych. Na Węgrzech dokonywało się to stopniowo i przez pierwsze trzy lata po wojnie panowała tam demokracja. Jeszcze w 1945 roku Bibó za namową przyjaciół przyjął stanowisko kierownika administracji publicznej w Ministerstwie Spraw Wewnętrznych. Dla niego wyzwolenie miało sens społeczny. Oto po czterystu latach beznadziejnych prób reformy społecznej, pojawia się szansa zburzenia skostniałego porządku społecznego. Tak oto pisał w eseju z 1947 roku:

[Rok 1945] jest tą chwilą, która znów otworzyła przed Węgrami możliwość włączenia się w proces zachodniego rozwoju społecznego. Nie ma nic dziwnego w tym, że przy-

36 Idem, Eltorzult magyar alkat..., s. 606.

37 Ibidem, s. 617. 
niosła ją nam obecność i wysiłek żołnierzy mocarstwa leżącego od nas na wschód, jeśli zważymy na to, że cała rewolucja [październikowa - F.T] to nic innego jak wielkie historyczne przedsięwzięcie, przekraczające wysiłki wszystkich wschodnioeuropejskich ludów podejmowanych w celu wyprowadzenia rosyjskiego ludu $\mathrm{z}$ impasu wschodniego rozwoju społecznego ${ }^{38}$.

Według Bibó przełom roku 1945 był naturalnym uzupełnieniem, zwieńczeniem zmian zapoczątkowanych jeszcze przez Wielką Rewolucję Francuską.

Rok 1945 stworzył warunki dla rozwoju węgierskiej demokracji. Jednak szybko okazało się, że w budowanie frontu ludowego, który wydawał się wówczas optymalną drogą reform społecznych w Europie, nie chcieli się włączyć węgierscy komuniści. W analizie ówczesnej rzeczywistości politycznej Bibó znów wraca do czynnika strachu, który uniemożliwia trzeźwy osąd sytuacji. Esej Kryzys demokracji węgierskiej (1945) rozpoczyna słowami:

Węgierska demokracja znajduje się w kryzysie. Znajduje się w kryzysie, bo żyje w strachu. Dręczy ją strach dwojakiego rodzaju: przed proletariatem, i przed reakcją. Jednak żaden z nich nie znajduje obiektywnych przesłanek ${ }^{39}$.

Nie ma podstaw do tego, by się bać, ale sam strach sprawia, że niebezpieczeństwo pojawia się rzeczywiście. Węgierscy komuniści są przekonani, że po drugiej stronie jest zacięta wobec nich wrogość, dlatego boją się marginalizacji w przypadku ewentualnej koalicji z jakąkolwiek partią. Inaczej niż socjaldemokraci, opowiadają się za całkowitym socjalizmem oraz bezpośrednimi i agresywnymi akcjami rewolucyjnymi:

Dyktatura proletariatu, jako dogmatyczne stanowisko występujące pod szyldem jedynego możliwego programu prawdziwie socjalistycznego, wciąż nakłania realizatorów rewolucji socjalistycznych do tego, by politykę frontu ludowego traktowali jako - obliczoną na krótką metę - taktykę, którą należy przy pierwszej sposobności odrzucićc ${ }^{40}$.

Czyżby ostatnią diagnozą Bibó miało być to, że histeria tym razem opanowała szeregi komunistów? Jak inaczej wytłumaczyć ich dążenie do zawłaszczenia pełni władzy?

Nadzieje Bibó na demokratyzację Europy Środkowej nie spełniły się. Już wcześniej miał złe przeczucie - wtedy, gdy w połowie 1946 roku odchodził z Ministerstwa. A jednak to krótkie powojenne intermezzo zapamiętał jako najważniejsze w swym życiu, zarówno od strony działalności praktycznej, jak i naukowej ${ }^{41}$. Udało się przecież wprowadzić pewne zmiany, jak przekształcenie starej i prowincjonalnej

38 Idem, A magyar társadalomfejlödés és..., s. 502.

39 Idem, A magyar demokrácia válsága (Kryzys demokracji węgierskiej, tłum. - F.T.), [w:] idem, Válogatott tanulmányok..., s. 15.

40 Idem, Sens europejskiego rozwoju społecznego, [w:] idem, Eseje polityczne, s. 249.

41 Wiele lat później zauważył pół żartobliwie, pół z wyrzutem, że na jego nagrobku powinien widnieć napis „István Bibó, żył w latach 1945-1948”. 
administracji czy reformę rolną, a wraz z nią likwidację wielkiej własności ziemskiej. Zniknął też czynnik, który tak długo stawiał barierę wszelkiemu rozwojowi - iluzja Węgier historycznych. Z czasem jednak okazało się, że w miejscu jednego sztywnego porządku społecznego zbudowany został inny i nie był to "porządek wolności”" ${ }^{2}$. W istocie czasy, które nastały, były tylko inną odmianą panowania „pańskości” i niosły ze sobą inną formę ucisku.

István Bibó do dziś nie doczekał się uznania poza granicami Węgier, choć z pewnością zasługuje na ważne miejsce w europejskim gronie lewicowych myślicieli społecznych XX wieku. Sándor Szilágyi nazywa go „socjalistą niezależnym”, podkreślając, że nie da się go zaszufladkować ani jako marksistę, ani socjaldemokratę, ani socjalistę chrześcijańskiego.

Potępiał wyzysk ze strony wielkich posiadaczy ziemskich, ze strony właścicieli fabryk, a także ze strony administracji państwowej, i trzymał się poglądu, że nadmiar ekonomicznej i administracyjnej władzy, skupionej w rękach jakiejś kliki mógłby zostać skutecznie odciążony przez ochotnicze zrzeszenia wolnych, zwykłych obywateli przybierających formę kooperacji, samoorganizacji oraz lokalnego samorządu ${ }^{43}$.

Innymi słowy - najskuteczniej jest wywierać konsekwentny i wytrwały nacisk na władzę za pomocą samorządów. Trudno oprzeć się wrażeniu, że brzmi to jak współczesna odmiana średniowiecznych „małych kręgów wolności”, które Bibó uważał za fundamenty zachodniej wolności obywatelskiej. Być może, gdyby dożył rewolucji polskiej „Solidarności”, właśnie w niej dopatrzyłby się historycznej syntezy ideałów demokratycznych i socjalistycznych, w którą tak silnie wierzył.

Czy istotnie są one do pogodzenia? Według Bibó największym grzechem marksizmu jest to, że nawołując do rewolucji i atakując przy tym burżuazyjne idee wolnościowe, rozerwał więź łączącą sprawę wolności i sprawę równości, która ukształtowała nowoczesne uczucia narodowe na Zachodzie. W ten sposób marksizm wbił klin między socjalizm i liberalizm. A przecież oba nurty dążą do realizacji programu wolnościowego: jeden poprzez zniesienie przywilejów płynących z posiadania, drugi - przywilejów płynących z urodzenia. Problem w tym, że owa wspólna istota zatarła się na skutek obciążenia obu nurtów odmiennymi celami. W ten sposób powołane do życia zostały dwa rodzaje arystokratyzmu: kapitalistyczny i komunistyczny. Oba mierzą system społeczny wielkością i skalą dobrobytu w danej wspólnocie. Bibó trzymał się innego kryterium - wewnętrznej równowagi danej społeczności, wysiłku nad ograniczaniem przemocy $w$ relacjach międzyludzkich i pracy nad budową sprawiedliwego społeczeństwa. To była dla niego sprawa zasadnicza.

42 Idem, Eltorzult magyar alkat..., s. 504.

43 S. Szilágyi, István Bibó, Central Europe’s political therapist, [w:] I. Bibó, Democracy, Revolution, Self-determination, selected writings, New York 1991. 
Hungarian historical impasses compared to European social development in István Bibó's perspective

The aim of the article is to discuss differences in social development of Western and Central Europe over the centuries, as an example of Hungary and based on István Bibós writings. Western-style development of the Central-European social organization was disrupted by political shocks at the beginning of the $16^{\text {th }}$ century. Consequently, Hungary lost independence and maintained its social fossilized structure. Furthermore, after the French Revolution the woken democratic and national feelings in Central-European nations turned the nations against themselves what resulted in a series of "political hysterias" in the region. The remaining part of this paper refers to Bibós reflections on disruption of Central Europe's fate and a role of the Marxist ideology.

Translated by Marta Antoniuk

\section{Венгерские исторические тупики на фоне европейского общественного развития в трактовке Иштвана Бибо}

Целью статьи является обсуждение расхождений между общественным развитием Западной и Центральной Европы на протяжении веков на примере Венгрии по сочинениям Иштвана Бибо. Развитие центральноевропейского общества, происходившее одновременно с развитием западноевропейского, было прервано политическими потрясениями в начале XVI века, в результате которых Венгрия потеряла независимость и сохранила ортодоксальный общественный уклад. После Французской революции же демократично-национальные чувства, пробужденные в центральноевропейских народах иначе, чем на Западе, обратили их друг против друга, что стало причиной серии «политических истерик» в регионе. Последняя часть работы касается размышлений Бибо о том, как остановить фатум Центральной Европы и роли, которую могла сыграть в этом процессе, но не сыграла, марксистская идеология.

Перевод Агнешка Поспишьль

\section{Bibliografia:}

Bibó I., Eseje polityczne, Kraków 2013 (książka zawiera cztery eseje: Nędza małych państw środkowoeuropejskich, Dzieje i przyczyny niemieckiej histerii politycznej, Sens europejskiego rozwoju społecznego, Kwestia Żydowska).

Bibó I., A magyar közigazgatásról (O węgierskiej administracji), http://mek.niif.hu/02000/02043/ html/323.html.

Bibó I., A magyar demokrácia válsága (Kryzys demokracji węgierskiej), http://mek.niif. $\mathrm{hu} / 02000 / 02043 / \mathrm{html} / 166 . \mathrm{html}$.

Bibó I., A magyar társadalomfejlődésé és az 1945. évi változás értelme (Węgierski rozwój społeczny i sens przełomu 1945 roku), http://mek.niif.hu/02000/02043/html/327.html.

Bibó I., Eltorzult magyar alkat, zsákutcas magyar történelem (Zniekształcony charakter węgierski i sprzeczna historia Węgier), http://mek.niif.hu/02000/02043/html/350.html.

Bibó I., Válogatott tanulmányok (1945-1949) (Dzieła wybrane Istvána Bibó), Budapest 1986, http://mek.niif.hu/02000/02043/html/index.html.

Dénes I. Z., Three Concepts of Liberty: István Bibó's, Hannah Arendt's and Isaiah Berlin's Interpretations, http://mek.oszk.hu/02200/02224/02224.htm\#10. 
Góralczyk B., Węgierski pakiet, Warszawa 2000.

Kemény I., Magyarság és Európa (Węgierskość i Europa), [w:] A hatalom humánizálasa, ed. I. Z. Dénes, Pécs 1993.

Kovács G., Hajnal István és Bibó István történelemszemlélete (Pogląd na historię Istvána Hajnala oraz Istvána Bibó), [w:] I. Z. Dénes, A szabadsàg kis körei, Budapest 1999.

Lakatos L., Hajnal István hatása, [w:] A hatalom humánizálasa (Humanitaryzacja władzy), ed. I. Z. Dénes, Pécs 1993.

Laignel-Lavastine A., Duchy Europy. Miłosz, Patocka, Bibó, Sejny 2012.

Szilágyi S., Bibó I., Central Europe’s political therapist, [w:] I. Bibó, Democracy, Revolution, Self-determination, selected writings, New York 1991.

Szücs J., Trzy Europy, Lublin 1995.

Franciszek Tyszka - ur. w 1982 roku w Warszawie. W 2008 r. ukończył filologię węgierską na Uniwersytecie Warszawskim, w 2011 r. studia podyplomowe w zakresie polityki monetarnej w Instytucie Nauk Ekonomicznych PAN. Obecnie jest doktorantem na Wydziale Historii i Cywilizacji w Europejskim Instytucie Uniwersyteckim we Florencji. 